\title{
Impact of an inducement to give high doses of amikacin and gentamicin on serum concentrations in critically ill patients with severe sepsis
}

\author{
C Roger ${ }^{1}$, B Louart ${ }^{1 *}$, L Muller $^{1}$, JA Roberts ${ }^{2}$, JY Lefrant ${ }^{1}$ \\ From ESICM LIVES 2015 \\ Berlin, Germany. 3-7 October 2015
}

\section{Introduction}

Low first-dose peak serum concentrations of amikacin and gentamicin are reported in intensive care unit (ICU) patients. $^{1}$

\section{Objectives}

The present study aimed at assessing the impact of giving high doses of amikacin $(30 \mathrm{mg} / \mathrm{kg})$ or gentamicin $(8 \mathrm{mg} / \mathrm{kg})$ in ICU patients with severe sepsis.

\section{Methods}

Single-center observational study. All ICU patients with clinical indication of aminoglycosides were eligible.ICU physicians were encouraged to administer maximal recommended doses of amikacin and gentamicin (30 and $8 \mathrm{mg} / \mathrm{kg}$, respectively). The first and subsequent doses and corresponding peak plasma concentrations were recorded. Guideline targets for serum concentrations were used with $\geq 60$ and $\geq 30 \mathrm{mg} / \mathrm{L}$ for amikacin and gentamicin, respectively. A target pharmacokinetic/ pharmacodynamic (PK/PD) ratio of 10-times the minimal inhibitory concentration (10xMIC) was also measured.

\section{Results}

Sixty-three ICU patients (39 males, $68 \pm 16$ years, $75 \pm 22$ $\mathrm{kg}, 168 \pm 8 \mathrm{~cm}$, SAPS II $=43 \pm 16)$ with severe sepsis and an indication for IV amikacin $(n=47)$ or gentamicin $(n=$ 16), were included. Pulmonary, abdominal and urinary tract infections were diagnosed in 56 patients. Infection was confirmed in 37 (59\%) patients. The target first-dose

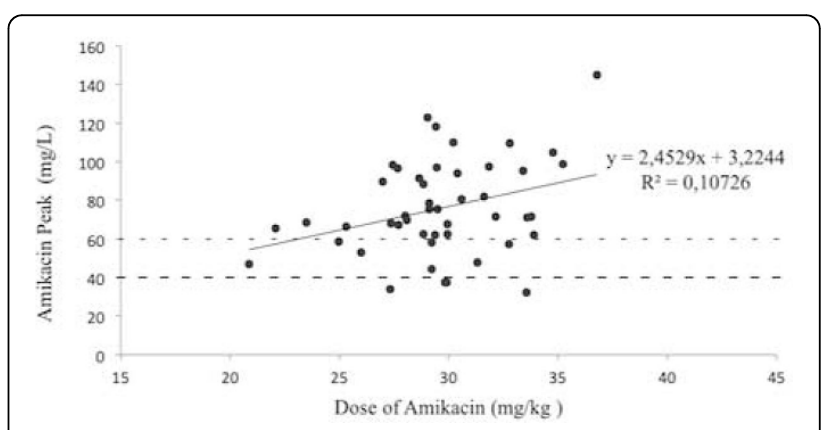

Figure 1 Amikacin peak concentrations after the first dose.

peak serum concentration was achieved in $37 / 63$ patients (59\%)(36/47 (77\%) and 1/16 (6\%) patient for amikacin and gentamicin, respectively). 59/63 (94\%) patients achieved the PK/PD target using the MIC data that was available from 21 patients. However, the subsequent injection should be cancelled in nearly half of patients due to a too high trough, without renal function impairment.

\section{Conclusions}

$30 \mathrm{mg} / \mathrm{kg}$ amikacin and $8 \mathrm{mg} / \mathrm{kg}$ gentamicin doses led to adequate peak serum concentrations in $59 \%$ patients using guideline targets.

\section{Authors' details \\ ${ }^{1}$ Nimes University Hospital, Nimes, France. ${ }^{2}$ University of Queensland, Brisbane, Australia.}

Published: 1 October 2015

${ }^{1}$ Nimes University Hospital, Nimes, France

Full list of author information is available at the end of the article

(c) 2015 Roger et al.; This is an Open Access article distributed under the terms of the Creative Commons Attribution License (http:// creativecommons.org/licenses/by/4.0), which permits unrestricted use, distribution, and reproduction in any medium, provided the original work is properly cited. 


\section{Reference}

1. de Montmollin E, Bouadma L, Gault N, Mourvillier B, Mariotte E, Chemam S, et al: Predictors of insufficient amikacin peak concentration in critically ill patients receiving a $25 \mathrm{mg} / \mathrm{kg}$ total body weight regimen. Intensive Care Med 2014, 40(7):998-1005.

doi:10.1186/2197-425X-3-S1-A402

Cite this article as: Roger et al:: Impact of an inducement to give high doses of amikacin and gentamicin on serum concentrations in critically ill patients with severe sepsis. Intensive Care Medicine Experimental 2015 3(Suppl 1):A402.

\section{Submit your manuscript to a SpringerOpen ${ }^{\circ}$ journal and benefit from:}

- Convenient online submission

- Rigorous peer review

- Immediate publication on acceptance

- Open access: articles freely available online

- High visibility within the field

- Retaining the copyright to your article

Submit your next manuscript at $\gg$ springeropen.com 